\title{
TINGKAT PENGETAHUAN SUAMI TENTANG PEMERIKSAAN IVA (INSPEKSI VISUAL ASAM ASETAT) SEBAGAI DETEKSI DINI CA CERVIX DI DUSUN DAPUR ENAM KEL. SEMBULANG KEC. GALANG, KOTA BATAM
}

\author{
Netty Herawaty Puba ${ }^{1}$, Nur Lestari ${ }^{2}$, Fina ${ }^{3}$ \\ ${ }^{1,2,3)}$ Program Studi Kebidanan, Sekolah Tinggi Ilmu Kesehatan Awal Bros Batam \\ Email korespondensi: nettyoerba21@gmail.com
}

\begin{abstract}
Abstrak
Kanker serviks adalah jenis kanker kedua terbanyak yang menyerang wanita di seluruh dunia. Meningkatnya insiden kematian akibat kanker servik disebabkan karena adanya rasa takut terhadap kanker dan masyarakat enggan melakukan pemeriksaan, sehingga kanker terdiagnosis setelah dalam stadium lanjut. Depresi dan prognosa yang kurang baik akibat kanker servik menurut Rasjidi dan Alliance Cancer Prevention tahun 2009, dapat diminimalkan dengan deteksi dini terhadap kanker servik, karena dengan deteksi dini kanker servik penderita dapat segera dilakukan terapi dengan cepat, namun sayangnya motivasi masyarakat untuk melakukan screening dini masih rendah sehingga perilaku terhadap kesehatan masih belum dilaksanakan dengan baik. Setelah dilakukan penyuluhan dapat memperbaiki dan meningkatkan derajat status kesehatan ibu khusunya dalam kesehatan reproduksi. Sasaran dalam kegiatan ini adalah suami yang mempunyai istri, sementara untuk tempat dan waktu kegiatan dilakukan di Dusun Dapur Enam Kel. Sembulang Kec. Galang, Kota Batam tahun 2019. Hasil akhir yang di harapkan dalam kegiatan ini adalah meningkatnya pengetahuan suami, sehingga suami dapat memotivasi istri untuk mau melakukan Pemeriksaan IVA (Inspeksi Visual Asam Asetat) dalam Deteksi Dini Ca Cervix.
\end{abstract}

Kata kunci: pengetahuan, suami, iva

\begin{abstract}
Cervical cancer is the second most common type of cancer affecting women worldwide. The increase in deaths from cervical cancer is due to the fear of cancer and the people who carry out the examination, so that cancer is diagnosed after it is in an advanced stage. Depression and unfavorable prognosis due to cervical cancer according to Rasjidi and the Alliance Cancer Prevention in 2009, can be reduced by early detection of cervical cancer, because with early detection of cervical cancer patients can be treated immediately, but the motivation of the community to perform early screening is still low. so that behavior towards health is still not implemented properly (Perez, 2006). After extension, it can improve and improve the health status of the mother, especially in health. The target of this activity is husband and wife who have wives, while the place and time of the activity is carried out in the Village of Nongsa, RT.8 Batam City in 2019. The expected final result in this activity is husband and wife who can motivate their wives to conduct Early Ca Cervix Examination (Visual Acetic Acid Examination).
\end{abstract}

Keywords: knowledge, husband, iva

\section{PENDAHULUAN}

Kanker serviks adalah jenis kanker kedua terbanyak yang menyerang wanita di seluruh dunia setelah kanker payudara. Pada tahun 2013 diperkirakan terdapat sekitar 528.000 kasus baru dan 266.000 kematian akibat kanker serviks. Sekitar 87\% kasus terjadi di negara yang sedang berkembang. Angka insiden kanker serviks di dunia per 100.000 
penduduk sebesar 15,1 sedangkan di Asia Tenggara sebesar 16,6.Jumlah kejadian kanker serviks pada tahun 2013 di Asia Tenggara sebanyak 50.566 kasus (ICO, 2014).

Data Globocan 2018, kasus baru kanker serviks di Indonesia mencapai 32.469 jiwa. Angka kematian akibat kanker serviks mencapai 18.279 per tahun. Ini artinya, ada sekitar 50 perempuan Indonesia meninggal dunia akibat kanker serviks. Angka itu melonjak tajam dibanding data Globocan pada 2012 yang menyatakan 26 perempuan Indonesia meninggal karena kanker serviks setiap tahunnya. World Health Organizatiton (WHO) menyebut kanker serviks sebagai jenis kanker nomor empat yang paling sering menyerang wanita dan mematikan. Ditambah, kanker ini paling banyak ditemukan di negara berkembang dibanding negara maju.

Meningkatnya insiden kematian akibat kanker servik disebabkan karena adanya rasa takut terhadap kanker dan masyarakat enggan melakukan pemeriksaan, sehingga kanker terdiagnosis setelah dalam stadium lanjut. Depresi dan prognosa yang kurang baik akibat kanker servik menurut Rasjidi dan Alliance Cancer Prevention tahun 2009, dapat diminimalkan dengan deteksi dini terhadap kanker servik, karena dengan deteksi dini kanker servik penderita dapat segera dilakukan terapi dengan cepat, namun sayangnya motivasi masyarakat untuk melakukan screening dini masih rendah sehingga perilaku terhadap kesehatan masih belum dilaksanakan dengan baik (Perez, 2006).

Saat ini upaya pencegahan sekunder dengan skrining masih menjadi fokus utama untuk menurunkan angka kejadian kanker serviks. Skrining kanker serviks dapat dilakukan melalui beberapa metode, diantaranya metode Inspeksi Visual Asam Asetat (IVA), dan tes pap smear. Skrining dilakukan untuk orang yang sudah pernah berhubungan seksual (Nurwijaya et al., 2010).

Kurangnya pengetahuan masyarakat mengenai kanker serviks dan keengganan untuk melakukan deteksi dini menyebabkan lebih dari $70 \%$ mulai menjalani perawatan medis justru ketika sudah berada dalam kondisi parah dan sulit disembuhkan. Tujuan dari deteksi dini adalah untuk menemukan kasus-kasus stadium dini sehingga kemungkinan penyembuhan dapat ditingkatkan.

Beberapa faktor yang dimungkinkan dapat mempengaruhi kunjungan deteksi dini kanker serviks, yaitu predispossing factor (tingkat pendidikan, pengetahuan, sikap, faktor risiko kanker serviks) enabling factor (akses informasi, keterjangkauan jarak, kepesertaan jaminan kesehatan) dan reinforcing factor (dukungan petugas kesehatan, dukungan anggota keluarga dan peran kader kesehatan).

\section{METODE}

Kegiatan ini diawali dengan terlebih dahulu melakukan pendekatan kepada tokoh masyarakat, pemuka agama dan tenaga kesehatan setempat. Kemudian melakukan pendekatan kepada suami dan ibu, setelah mendapatkan izin dan waktu yang tepat maka diadakan penyuluhan dengan metode diskusi kelompok kepada suami-suami yang mempunyai istri terkait pemeriksaan IVA (Inspeksi Visual Asam Asetat sebagai deteksi dini ca-serviks. 


\section{Dokumentasi kegiatan}
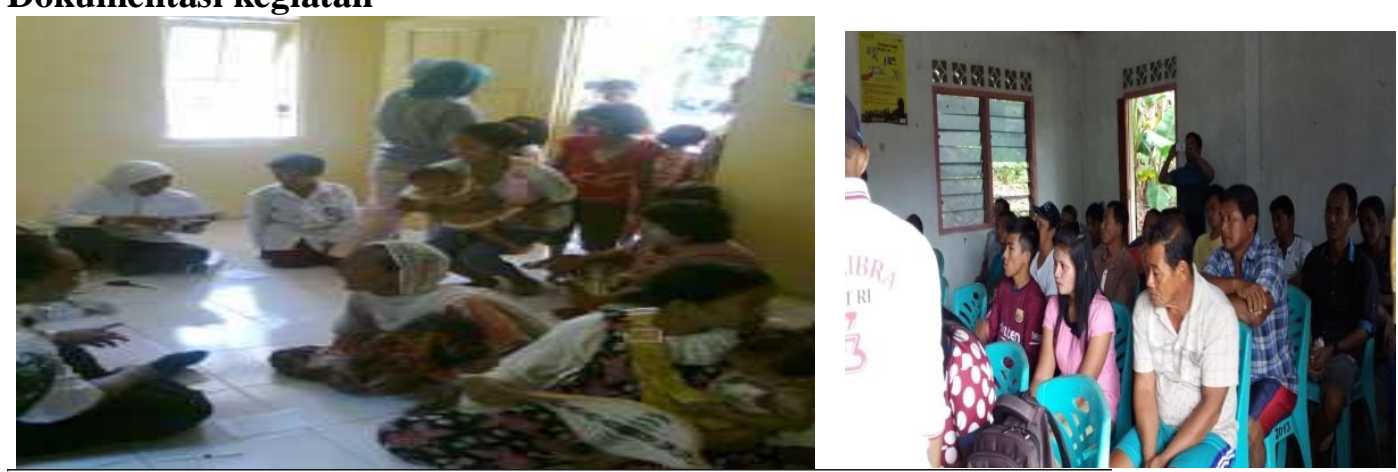

APA

PEMBRIKSAAN "IVA"

Imu?

TUJAYITA

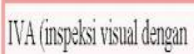

Mengurangi angaka kematian ibu

asam astati) menupakan cara

sedertana untuk mendetelki

dari pentrakit dengan pengobatan

dini. Untuk mengetahuik kelainan

yang terigadi padal leher rahim.

kanker leher ahimims sedini

mungkin.

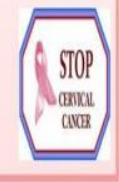

Mengapa di Rekomendasiakn

untuk tes IVA?

Karena merupakan pemeriksaan skrining altematife dari pap smear karena murah, praktils, sangat mudah untuk dilaksanakan dan peralatan sederhana serta dapat dilakukan oleh tenaga kesehatan selain dokter.
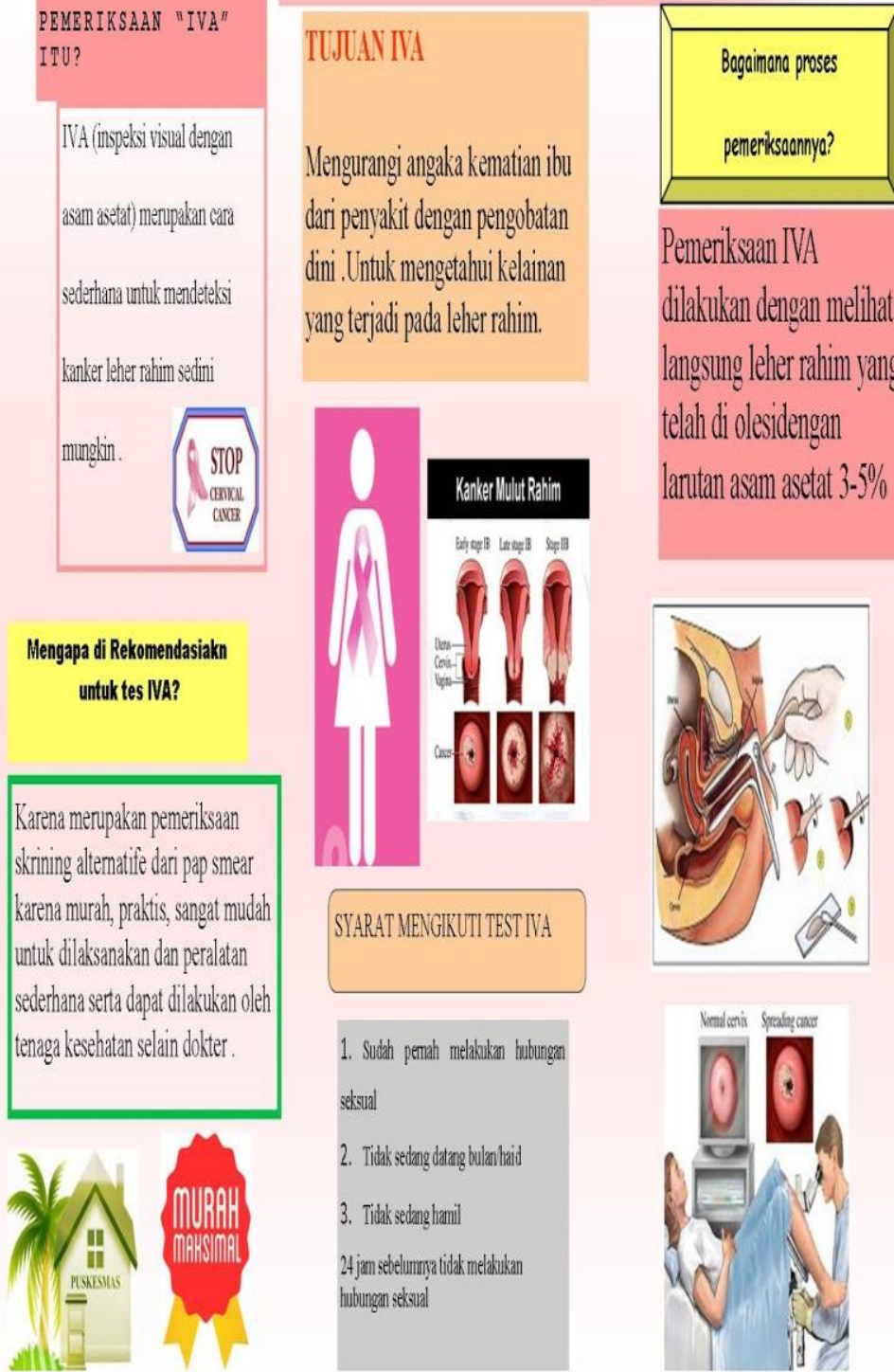

Pemeriksaan IVA

dilakukan dengan melihat langsung leher rahimin vang telah di diesidengan

lantian asam asctat 3.5\%
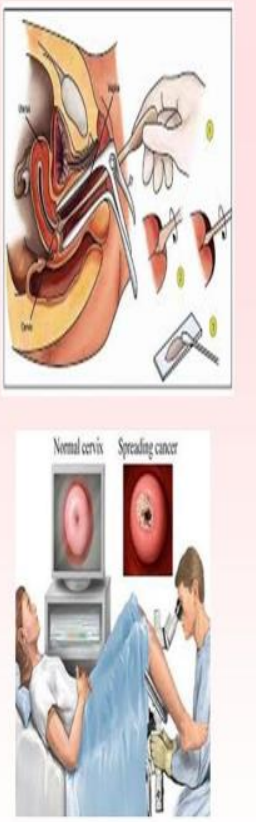


\section{HASIL DAN PEMBAHASAN}

Hasil

\section{Tahap persiapan}

Kegiatan ini diawali dengan terlebih dahulu melakukan pendekatan kepada tokoh masyarakat, pemuka agama dan tenaga kesehatan setempat. setelah mendapatkan izin dan waktu yang tepat maka diadakan penyuluhan dengan metode diskusi kelompok kepada suami-suami yang mempunyai istri terkait pemeriksaan IVA (Inspeksi Visual Asam Asetat sebagai deteksi dini ca-serviks.

2. Tahap implementasi

Pelaksanaan kegiatan ini dilaksanakan pada Bulan Maret Tahun 2020, dengan melibatkan 1 orang dosen dan dua orang mahasiswa. Kegiatan ini diikuti oleh 25 suami, dan istri yang juga ikut melaksanakan pemeriksaan IVA.

\section{Tahap Evaluasi}

Evaluasi hasil dari kegiatan ini adalah peserta dapat mengetahui tentang pengertian, keuntungan, syarat dan waktu untuk melakukan pemeriksaan IVA, dari hasil post test didapatkan peserta yang memiliki pengetahuan baik sebanyak sepuluh orang atau $72 \%$.

\section{PEMBAHASAN}

Pada kegiatan ini peserta pelatihan adalah suami yang memiliki istri yang ada di Dusun Dapur Enam Kel. Sembulang Kec. Galang, Kota Batam Tahun 2019 sebanyak 25 orang. Dukungan suami berupa motivasi, dorongan, informasi, empati ataupun bantuan yang dapat membuat individu lainya merasa lebih tenang dan aman. Dukungan suami dapat mendatangkan rasa senang, rasa aman, rasa puas, rasa nyaman dan membuat individu yang bersangkutan merasa mendapatkan dukungan emosional yang dapat mempengaruhi kesejahteraan jiwa manusia, Setyarini (2009).

Faktor-faktor yang menyebabkan wanita tidak melakukan tindakan deteksi dini kanker serviks adalah rendahnya persepsi kerentanan terhadap penyakit kanker serviks yang dirasakan wanita, kurangnya pengetahuan tentang pentingnya deteksi dini kanker serviks dan faktor-faktor resiko kanker serviks seperti rasa takut dan sakit terhadap deteksi diini kanker serviks, mahalnya biaya pemeriksaan dan rasa malu ibu dilakukannya pemeriksaan IVA tersebut.

Dukungan sosial keluarga dapat berupa dukungan sosial keluarga internal, seperti dukungan dari suami/istri atau dukungan dari saudara kandung atau dukungan sosial keluarga eksternal. Suami sebagai kepala rumah tangga dapat berperan serta dalam kesehatan Reproduksi. Bentuk peran serta tersebut dapat berupa pemberian dukungan terhadap kesehatan reproduksi (Setiati, 2009)

\section{SIMPULAN}

Berdasarkan hasil kegiatan PKM terkait Tingkat Pengetahuan Suami Tentang Pemeriksaan Iva (Inspeksi Visual Asam Asetat) Sebagai Deteksi Dini Ca Cervix di Dusun Dapur Enam Kel. Sembulang Kec. Galang, Kota Batam Tahun 2019 dapat disimpulkan bahwa tingkat pengetahuan suami mayoritas memiliki pengetahuan baik. 


\section{SARAN}

Dalam kegiatan PKM ini, kami menyadari bahwa dalam penulisan makalah ini masih banyak kekurangan, oleh sebab itu kami sangat mengharapkan kritik dan saran yang membangun. Dalam pembuatan makalah ini kami tidak luput dari kesalahan

\section{UCAPAN TERIMA KASIH}

Penulis mengucapkan terima kasih kepada semua pihak yang telah membantu kelancaran pelaksanaan Pengabdian Kepada Masyarakat ini di Dusun Dapur Enam Kel. Sembulang Kec. Galang, Kota Batam Tahun 2019, dan segenap civitas akademika STIKes Awal Bros Batam dan Yayasan Awal Bros Bangun Bangsa.

\section{DAFTAR PUSTAKA}

1. ICO (Information Centre on HPV and Cancer), 2014. Human Papilloma Virus and Related Disease Report for Indonesia [Accessed 02 Juni 2019] http://www.hpvcentre.net/statistics/reports/ IDN.pdf.

2. Kartono. 2006. Perilaku Manusia. Jakarta : EGC

3. Melianti Mira. 2011. Skining Kanker Serviks dengan Metode Inspeksi Visual deang Asam Asetat (IVA) test.

4. Nasir. 2005. Metode Penelitian. Bogor : Ghalia Indonesia

5. Novel S.Sinta dkk. 2010. Kanker Serviks dan Infeksi Human Pappilomavirus (HPV). Jakarta : Javamedia Network

6. Nurwijaya, Hartati, Andrijono \& HK, Suhaemi, 2010. Cegah dan Deteksi Dini Kanker Serviks.Jakarta: Gramedia

7. Samadi Priyanto .H. 2010. Yes, I Know Everything about KANKER SERVIK. Yogyakarta : Tiga Kelana

8. Setiati, E. 2009. Waspada 4 Kanker Ganas Pembunuh Wanita. Yogyakarta: Andi.

9. Setyarini (2009). Faktor-Faktor yang Berhubungan Dengan Kanker leher Rahim Di RSUD Dr.Moewardi Surakarta. Skripsi

10. Sukaca E. Bertiani. 2009. Cara Cerdas Menghadapi KANKER SERVIK (Leher Rahim). Yogyakarta: Genius Printika 